\title{
DURABILITY INDEX OF DRY SLUDGE INCORPORATED CONCRETE WHEN USED AS SAND REPLACEMENT.
}

\author{
B.D Ikotun ${ }^{1 *}$, R.P Mathye ${ }^{2}$, G.C Fanourakis ${ }^{3}$ \\ ${ }^{1}$ Department of Civil and Chemical Engineering, University of South Africa, \\ ikotubd@unisa.ac.za \\ ${ }^{2}$ Sandton/Alex, Johannesburg Water, South Africa. Patrick Mathye \\ patrick.mathye@jwater.co.za \\ ${ }^{3}$ Department of Civil Engineering Technology, University of Johannesburg, \\ Doornfontein Campus, Johannesburg, South Africa. \\ georgef@uj.ac.za
}

\begin{abstract}
It is paramount to look for alternative ways of disposing dry sludge, as present disposal methods are environmentally unsustainable. Hence, the investigation on the possible inclusion of dry sludge in concrete. More specifically, this paper presents and discusses the effect of dry sludge used as a partial sand replacement on concrete durability indexes. Two durability indexes were assessed in this article, which are Oxygen permeability index (OPI) and chloride conductivity index (CCI). The OPI gives an indication of concrete's resistance to the flow of water through continuous pores, at a given pressure and temperature, while the CCI provides an indication of concrete's resistance to chloride infiltration. Dry sludge was used as a sand replacement, in the proportion of $0 \%, 1 \%, 3 \%$ and $5 \%$. The $0 \%$ sample served as the control sample. Three water cement ratios (W/C), of 0.67, 0.69 and 0.80 , were assessed. The samples were water cured for 28 and 90 days before testing. The results showed that higher $\mathrm{W} / \mathrm{C}$ and higher sludge replacement had a detrimental effect on concrete OPI. In addition, the CCI results show that dry sludge had a positive ionic reaction and good sulphuric attack resistance on concrete.
\end{abstract}

Keywords: Dry sludge, Oxygen Permeability Index, Chloride Conductivity Index, water cement ratio. 


\section{INTRODUCTION}

Wastewater sludge is defined as the residual material removed from wastewater treatment facilities and processes. The production of wastewater sludge from treatment plants is in a rise all over the world. The impact on environmental management makes the disposal of wastewater sludge a serious problem for wastewater treatment managers. Some solutions to this problem include the use of this by-product in the agricultural industry and construction fields. However, due to its level of hazardousness; more restrictions are placed on the disposal methods, as it is environmentally unsustainable to dispose wastewater sludge. In South Africa, especially the city of Johannesburg metropolitan municipality, the generation of waste is increasing rapidly due to urban increasing development. In the City of Johannesburg Integrated Annual Report 2014/15, an estimated population of 3.8 million are reside in and around the city. This rapid increase of population and concomitant generation of waste has an adverse effect on humans and the environment. To ensure sustainability of human health and the environment, suitable treatment and innovative disposal methods of dry wastewater sludge are required (Al-Malack et al, 2002).

One disposal method that warrants investigation is the incorporation of dry wastewater sludge in concrete production. In order to assess the quality of dry wastewater sludge incorporated concrete, the durability of the composite concrete needs to be investigated. Durability of concrete has always been of great concern to researchers because it determines the longevity of concrete structures. According to Alexander et al., 2001 and Alexander, 2004, "durability may be defined as the ability of a material or structure to withstand the service conditions for which it is designed over a prolonged period without significant deterioration". Natural occurrences like weathering, abrasion, high temperature, chemical ingress and gases have an environmental effect on the durability of concrete (Alexander, 2004). The properties of concrete that affect durability revolve around the following; permeability, sorptivity, sulphate attack, alkali-aggregate reaction and carbonation (Ha-Won and Seung-Jun, 2007). The durability indexes that will be used to assess the quality of the dry wastewater sludge incorporated concrete in this study are Oxygen Permeability Index, Sorptivity and Chloride Conductivity.

The concrete's durability is mostly assessed by the degree through which harmful agents can penetrate the concrete (Ballim and Alexander, 2005) and due to the characteristic of its pore structure (De Schutter, 2004). According to Osborne, 1999, durable concrete must be dense and impermeable to liquids and gases. It should possess high intrinsic resistance to external penetration of ionic species such as sulphates and chloride. Many structural failures in concrete can be linked to poor durability. The aim of this study is to investigate the effect of wastewater dry sludge on concrete durability when used as a replacement of sand. 


\section{EXPERIMENTAL DETAILS}

\subsection{Materials}

The main materials used for this study were Portland cement CEM II/A-M (V-L) 42.5R from Afrisam, South Africa; wastewater dry sludge from the Northern Works Treatment Plant, Johannesburg; Crusher sand and coarse stone $(22.4 \mathrm{~mm})$ from Afrisam, Eikenhof quarries, South Africa.

\subsection{Sample Preparation}

Concrete samples were mixed according to SANS 5863, 2006, cast in $100 \mathrm{~mm}$ cube moulds and kept moist for 24 hours before demoulding. The samples were watercured at a constant temperature of approximately $22{ }^{\circ} \mathrm{C}$ for 28 and 90 days. Four different concrete mixes were prepared based on $0 \%, 1 \%, 3 \%$ and $5 \%$ of sand replacement (with sludge), at three water-cement ratios (W/C) of 0.67, 0.69 and 0.80 . The control concrete samples were prepared with $0 \%$ sludge. The mix proportions for $0.168 \mathrm{~m}^{3}$ quantity of concrete, used for this study are presented in Table 1 .

The durability index samples were prepared according to SANS 3001-CO3-1, 2015 by coring representative samples of $68 \mathrm{~mm}( \pm 2 \mathrm{~mm})$ diameter samples from the 100 $\mathrm{mm}$ cubes samples after the curing periods. Each $68 \mathrm{~mm}$ core was then saw-cut into $30 \mathrm{~mm}( \pm 2 \mathrm{~mm})$ thick slices and be kept in an oven for 7 days at $50 \pm 2^{\circ} \mathrm{C}$ at less than $20 \%$ relative humidity. The oven dried $68 \times 30 \mathrm{~mm}$ cylindrical prism samples were then tested to determine Oxygen Permeability Index (OPI) and Chloride Conductivity Index (CCI). The core samples and the prism samples are shown in Figure 1 and 2, respectively.

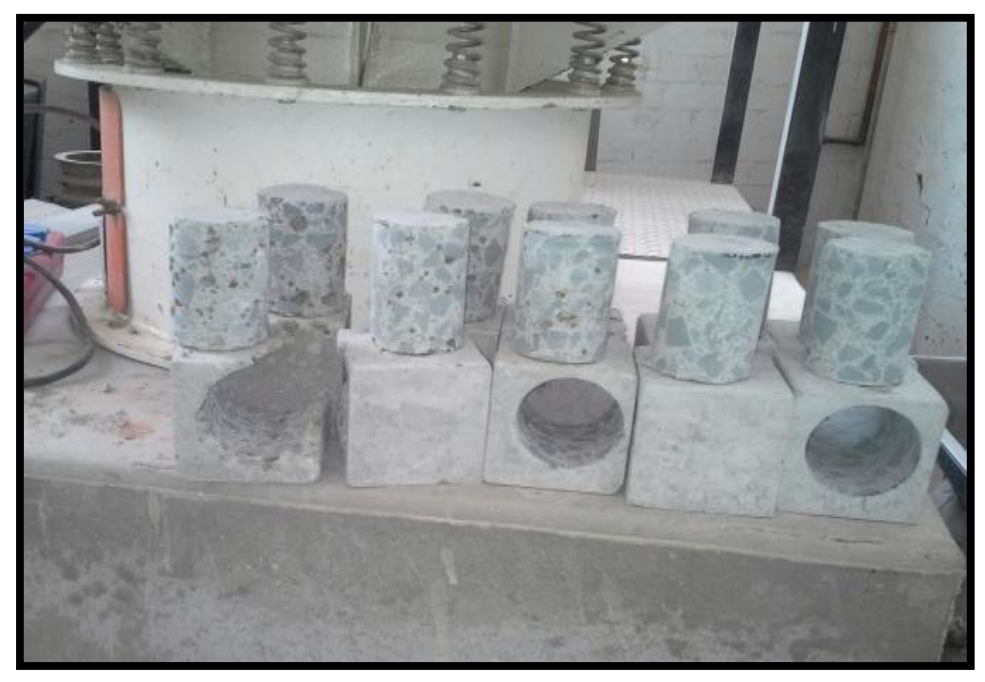

Figure 1: Cored concrete samples 


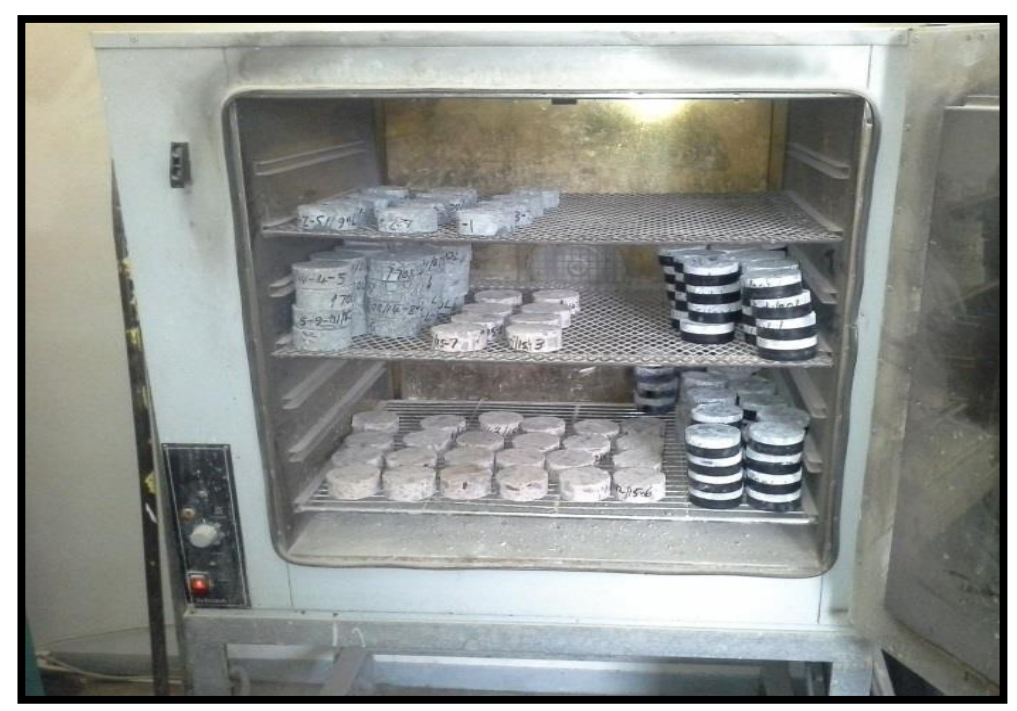

Figure 2: Prisms samples for durability index tests

Table 1: $0.168 \mathrm{~m}^{3}$ mixture proportion for the Concrete Samples.

\begin{tabular}{|c|c|c|c|c|c|c|c|c|}
\hline Mix & Samples & $\begin{array}{c}\text { Ceme } \\
\text { nt } \\
(\mathrm{kg})\end{array}$ & $\begin{array}{l}\text { Crusher } \\
\text { sand } \\
\text { (kg) }\end{array}$ & $\begin{array}{c}22.4 \\
\text { mm } \\
\text { Stone } \\
\text { content } \\
\text { (kg) }\end{array}$ & $\begin{array}{l}\text { Municipal } \\
\text { water (kg) }\end{array}$ & $\begin{array}{l}\text { Sludg } \\
\text { e } \\
\text { replac } \\
\text { ement } \\
\text { (kg) }\end{array}$ & $\mathrm{W} / \mathrm{C}$ & $\begin{array}{c}\text { Slump } \\
(\mathbf{m m})\end{array}$ \\
\hline MIX A & $\begin{array}{l}\text { Control } \\
(0.67)\end{array}$ & 52.42 & 170.18 & 176.40 & 34.94 & 0.00 & 0.67 & 100 \\
\hline MIX B & $\begin{array}{l}\text { Control } \\
(0.69)\end{array}$ & 50.40 & 166.32 & 176.40 & 34.94 & 0.00 & 0.69 & 100 \\
\hline MIX C & $\begin{array}{c}\text { Control } \\
(0.80)\end{array}$ & 42.00 & 176.40 & 176.40 & 34.94 & 0.00 & 0.80 & 100 \\
\hline \multirow[t]{3}{*}{ MIX A } & $\begin{array}{c}1 \% \\
\text { Sludge/0.67 }\end{array}$ & 52.42 & 162.62 & 176.40 & 34.94 & 1.68 & 0.67 & 105 \\
\hline & $\begin{array}{c}3 \% \\
\text { Sludge/0.67 }\end{array}$ & 52.42 & 159.43 & 176.40 & 34.94 & 4.87 & 0.67 & 115 \\
\hline & $\begin{array}{c}5 \% \\
\text { Sludge/0.67 }\end{array}$ & 52.42 & 156.07 & 176.40 & 34.94 & 8.23 & 0.67 & 15 \\
\hline \multirow[t]{3}{*}{ MIX B } & $\begin{array}{c}1 \% \\
\text { Sludge/0.69 }\end{array}$ & 50.40 & 164.64 & 176.40 & 34.94 & 1.68 & 0.69 & 125 \\
\hline & $\begin{array}{c}3 \% \\
\text { Sludge/0.69 }\end{array}$ & 50.40 & 161.28 & 176.40 & 34.94 & 5.04 & 0.69 & 125 \\
\hline & $\begin{array}{c}5 \% \\
\text { Sludge/0.69 }\end{array}$ & 50.40 & 157.92 & 176.40 & 34.94 & 8.23 & 0.69 & 60 \\
\hline \multirow[t]{3}{*}{ MIX C } & $\begin{array}{c}1 \% \\
\text { Sludge/0.80 }\end{array}$ & 42.00 & 174.72 & 176.40 & 34.94 & 1.84 & 0.80 & 110 \\
\hline & $\begin{array}{c}3 \% \\
\text { Sludge/0.80 }\end{array}$ & 42.00 & 172.87 & 176.40 & 34.94 & 5.38 & 0.80 & 115 \\
\hline & $\begin{array}{c}5 \% \\
\text { Sludge/0.80 }\end{array}$ & 42.00 & 169.34 & 176.40 & 34.94 & 8.90 & 0.80 & 75 \\
\hline
\end{tabular}




\subsection{Test Procedure}

\subsubsection{Oxygen Permeability Index Test}

After the samples were kept in an oven for 7 days at $50 \pm 2{ }^{\circ} \mathrm{C}$, they were subjected to the Oxygen Permeability Index (OPI) testing procedure according to SANS 3001CO3-2, 2015.

\subsubsection{Chloride Conductivity Index Test}

The Chloride Conductivity test processes follow the saturation method and allowed for a pressure of $-75 \mathrm{kPa}$ and $-80 \mathrm{kPa}$ in a vacuum pressure, following the procedure outlined in SANS 3001-CO3-3, 2015.

\section{RESULTS AND DISCUSSION}

\subsection{Oxygen Permeability Index (OPI)}

The OPI results for concrete samples cured for 28 days and 90 days are presented in Figure 3. According to Alexander et al., 2001 a measure of permeability of a Good to Excellent concrete should have an index mean value of 9.5 to above 10. At both 28 days and 90 days curing periods, the control sample showed a good to excellent index for all the three W/C's $(0.67,0.68$ and 0.8$)$. The OPI of $1 \%, 3 \%$ and $5 \%$ sludge replacement samples showed favourable results (good to excellent index) for 0.67 and $0.69 \mathrm{~W} / \mathrm{C}$ at the 28 days curing period. However, very poor to poor indices were observed for the 90 days curing period for $1 \%$ and $3 \%$ sludge replacement samples. In addition, the samples with $0.8 \mathrm{~W} / \mathrm{C}$, for all sludge replacements $(1 \%, 3 \%$ and 5\%), portrayed a very poor to poor index, at both 28 days and 90 days curing periods. Generally, the results of all samples at both ages showed that the higher the $\mathrm{W} / \mathrm{C}$, the poorer the OPI. However, the samples with $5 \%$ sludge replacement showed inconsistency with the general W/C trend observation as, for this sample, the $0.69 \mathrm{~W} / \mathrm{C}$ had a better OPI than the $0.67 \mathrm{~W} / \mathrm{C}$ at both curing ages. Another counterintuitive trend was identified in the case of the samples with a W/C of 0.8 , where the samples with a replacement of $5 \%$ obtained a higher OPI than the samples with $3 \%$ replacement (at both curing ages).

From the results, it can be deduced that, the simultaneous increase of water content and sludge replacement had adverse effect on permeability. According to Alexander et al., 2001 through the OPI-Log scale, these mean values represent a variability check of good compaction of the concrete and the level of permeability. It can therefore be resolved that both water content and wastewater sludge replacement have direct impact on the permeability behaviour of concrete. The high organic matter in the sludge concrete compromises the achievement of good compaction and hence makes it more permeable in its fresh and hardened state (De Schutter, 2004). According to Mackechnie et al., 2002, there is a good relationship between the OPI values for concretes evaluated after 28 days and carbonation depths; this inference makes OPI a good indicator of carbonation resistance. It was evident in this research 
that at 28 days, the W/C's $(0.67,0.69)$ for the $0 \%, 1 \%, 3 \%$ and $5 \%$ sludge replacement had mean index values between 9.5 to above 10 .

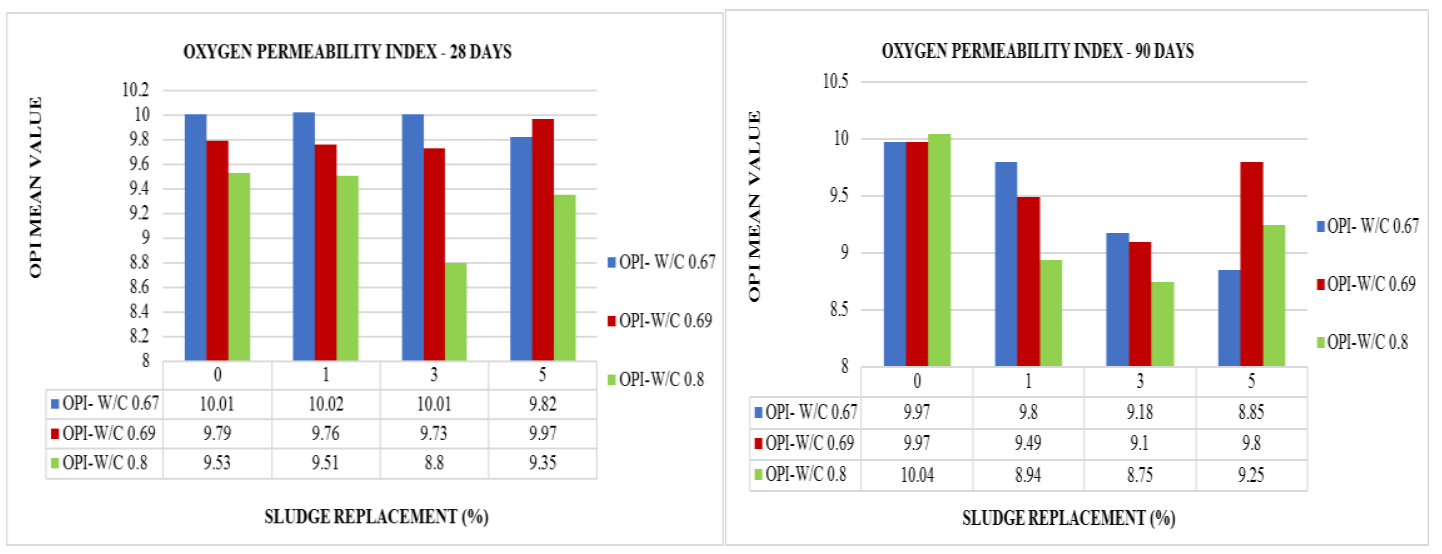

Figure 3: Oxygen Permeability Index - at 28 and 90 days periods

\subsection{Chloride Conductivity Index Test}

Figures 4 represents the chloride conductivity findings on the samples cured for 28 days and 90 days. The chloride conductivity test is a quality control parameter that is used to evaluate the resistance of chloride ingress by concrete (Mackechnie et al., 2002; Otieno and Alexander, 2015).

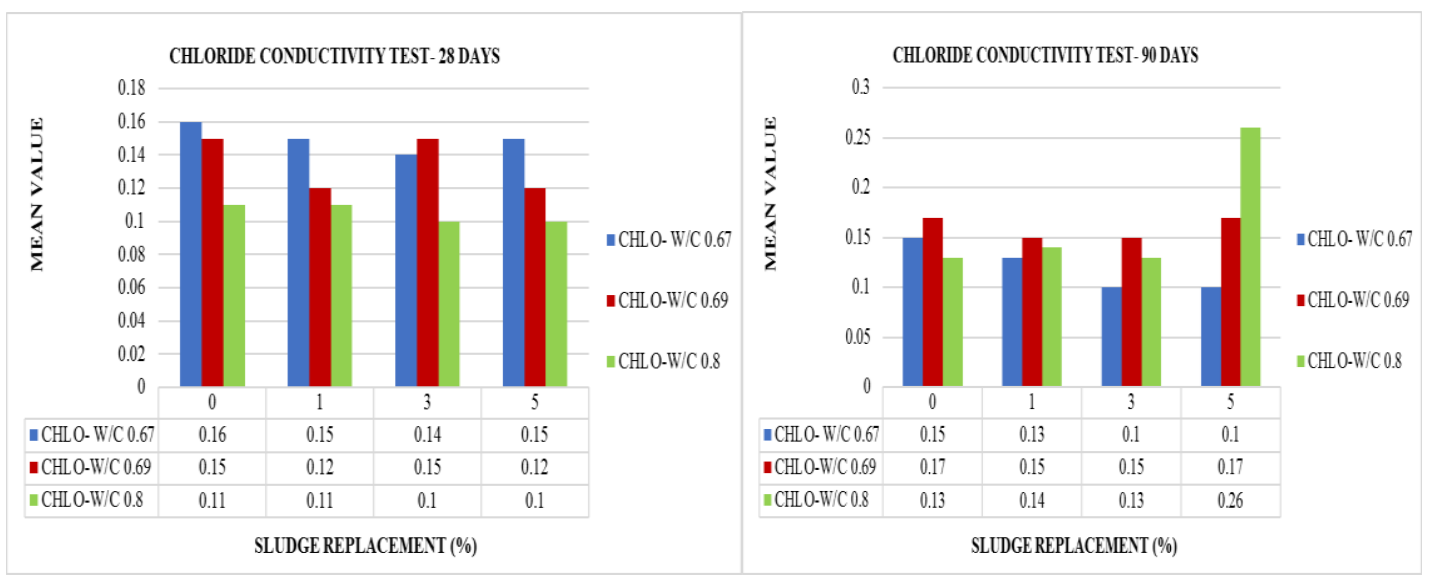

Figure 4: Chloride Conductivity Tests - at 28 and 90 days periods

At 28 days, the concrete specimens with $0 \%, 1 \%, 3 \%$ and $5 \%$ sludge replacements all had Average Conductivity Values (ACV) of less than 0.75 across the W/C of $0.67,0.69$ and 0.8 . However, the control mix with $0 \%$ sludge replacement had ACV's of $0.16,0.15$ and 0.11 for the W/C $0.67,0.69$ and 0.8 , respectively It can be deduced that water content did not negatively impact the chloride conductivity of the concrete, therefore according to Alexander et al., 2001, these concretes specimens had an excellent chloride conductivity index. At 90 days, the 5\% sludge replacement 
indicated an increase in ACV with an increase in W/C. Nevertheless, at 90 days and $5 \%$ replacement, the mix with a W/C of $0.8 \mathrm{had}$ an ACV of 0.26 . This value is still within the excellent measure of the index value. The outcome can be attributed to the fact that, an increase in water content and sludge replacement had the long-term effect on the chloride conductivity of concrete sludge.

According to Alexander, 2004, concrete with an Average Conductivity Value (ACV) of less than 0.75 , represents an excellent chloride conductivity value. The low ACV ranges for the Chloride Conductivity Index are not a measure of compaction; however, they measure the conductivity of the ionic components of concrete under potential difference. This conductivity potential is related to the chloride diffusion properties of the concrete (Mackechnie et al., 2002). These findings are supported by this research where the ionic conductivity index was all-good throughout all mixes. De Schutter, 2004, concluded that concrete with sludge replacement had a positive ionic reaction and good sulphuric attack resistance. This agrees with the results obtained for all the samples at sludge replacement of $1 \%, 3 \%$ and $5 \%$.

\section{CONCLUSIONS}

The results presented and discussed in this article showed that sludge replacement in concrete had a direct effect on the expected durability behaviour of concrete. When considering all the mixes for both the 28 and 90 days ages, it was deduced that the simultaneous increase of $\mathrm{W} / \mathrm{C}$ and sludge replacement resulted in an increase in the OPI (decrease in permeability). This trend was not observed in the samples with $5 \%$ replacement, which obtained a higher OPI than the samples with $3 \%$ replacement (at both ages). However, at 0.67 and $0.69 \mathrm{~W} / \mathrm{C}$, good to excellent OPI results were recorded for $1 \%$ and $3 \%$ sludge replacement samples. In the case of the Chloride Conductivity Index (CCI) tests, at both 28 and 90 days ages, all the mixes achieved Average Conductivity Values (ACV) of less than 0.75 . As such these are "excellent" chloride conductivity values. From these results, it was evident that no trend existed between W/C and conductivity. These CCI results confirmed that sludge replacement had a positive ionic reaction and good sulphuric attack resistance.

\section{REFERENCES}

Alexander, M.G., Mackechnie, J.R., and Ballim, Y. (2001) Guide to the use of durability indexes for achieving durability in concrete structures, Research monograph no 2, published by the Department of Civil Engineering, University of Cape Town in collaboration of University of the Witwatersrand, pp. 5-25.

Alexander, M. G. (2004) Durability indexes and their use in concrete engineering, International RILEM Symposium on Concrete Science and Engineering: A Tribute to Arnon Bentur. Print-ISBN: 2-912143-46-2, e-ISBN: 2912143586, Publisher: RILEM Publications SARL, pp. 9-22. 
Al-Malack, M.H., Abuzaid, N.S., Bukhari, A.A., and Essa, M.H. (2002) Characterization, Utilization and Disposal of Municipal Sludge: The State of the Art, The Arabian Journal for Science and Engineering, Volume 27, Number 1B.

Ballim, Y. and Alexander, M.G. (2005) Towards a performance-based specification for concrete durability, African Concrete Code Symposium, 206-218.

City of Johannesburg Integrated Annual Report 2014/15: (South Africa - 2014).

De Schutter, G. 2004. Evaluation of Water Absorption of Concrete as a Measure for Resistance against Carbonation and Chloride Migration. Journal of Materials and Structures, 37(273), 591-596.

Ha-Won S. and Seung-Jun K. (2007) Permeability characteristics of carbonated concrete considering capillary pore structure, Cement and Concrete Research, 37, 909-915.

Osborne, G.J. (1999) Durability of Portland blast - furnace slag cement concrete, Cement and Concrete Composites, 21, 11-21.

SANS 5863: 2006: Concrete testing - Compressive strength of hardened concrete.

SANS 3001-CO3-1:2015, Concrete durability index testing - Preparation of test specimens.

SANS 3001-CO3-2:2015, Concrete durability index testing - Oxygen permeability test.

SANS 3001-CO3-3:2015, Concrete durability index testing - Chloride conductivity test.

Mackechnie, J.R., Andrade, C. \& J.Kropp, E.D and Alexander, M.G. (2002). A pragmatic prediction model for chloride ingress into concrete. 3rd RILEM Workshop on Testing \& modelling the chloride ingress into concrete. 9 - 10 September, 2002. France: RILEM. 65-76.

Otieno M., Alexander M., 2015 Chloride conductivity testing of concrete - past and recent developments. Journal of the South African Institution of Civil Engineering, Vol. 57/ No. 4 ISSN 1021-2019. 